\title{
Aplicaciones extraorales del bisturí piezoeléctrico
}

\author{
Extraoral uses of a piezoelectric surgical cutting tool
}

\section{J. González Lagunas, J. Molina Montes, J. Mareque Bueno}

\begin{abstract}
Resumen: Presentamos nuestra experiencia con el empleo de un bisturí piezoeleéctrico con el fin de efectuar diferentes osteotomias extraorales, Estas indicaciones no se han presentado previamente en la literatura. En lus últimos 6 meses hemos utilizado este intrumento para efectuar osteotomías en el cóndilo y en la eminencia articular, para tomar injerto de calota craneal y para realizar las osteotomias de la rinoplastia. Este instrumento permite una inea de osteotomia precisa sin el riesgo de lesionar los tejidos blandos vecinos. Se discuten las ventajas e inconvenientes del instrumento según el procedimiento realizado.
\end{abstract}

Palabras clave: Articulación temporomandibular; Rinoplastia; Injertos óseos; Ultrasonidos; Osteotomía.

Recibido: 05.06 .07

Aceptado: 16.06 .08

\begin{abstract}
We report our experience with the use of a piezoelectric surgical cutting tool in performing extraoral osteotomies. These indications have not been reported previously in the literature. In the last 6 months we have used this instrument to perform osteotomy on the temporomandibular condyle and articular eminence, to obtain grafts from the skull, and to perform osteotomy for rhinoplasty. This instrument can be used to makes an osteotomy cut without risk of injuring adjacent soft tissues. Its advantages and disadvantages are discussed in accordance with the procedure performed.
\end{abstract}

Key words: Temporomandibular joint; Rhinoplasty; Bone grafts; Ultrasound; Osteotomy.

\section{Correspondencia:}




\section{Introducción}

La piezocirugía aprovecha la capacidad de corte de bisturís que microvibran con una frecuencia de ultrasonidos. Los tejidos blandos que contactan con el material vibratorio no son lesionados, por lo que es un instrumento ideal para ser utilizado en el territorio limitrofe entre los tejidos blandos y el hueso, ${ }^{1}$ reduciendo así el riesgo de traumatizar los tejidos blandos vecinos.

En el territorio maxilofacial existe una estrecha relación entre el hueso, los nervios y los vasos vecinos. La técnica ha sido utilizada en diferentes osteotomías intra y extraorales del territorio maxilofacial con el fín de aprovechar su corte "selectivo" y minimizar así el trauma quirúrgico a los tejidos adyacentes. El objetivo de este artículo es presentar nuestra experiencia con nuevas aplicaciones del uso de un bisturí piezoeléctrico en diferentes osteotomías extraorales del territorio craneofacial.

\section{Material y método}

En todos los pacientes se ha utilizado el mismo instrumento (Mectron Medical Technology, Italia) para efectuar las diferentes osteotomías. Se emplea una frecuencia de oscilación de 25-30 KHz para osteotomizar el hueso sin afectar a los tejidos blandos vecinos. El dispositivo se emplea en su máximo nivel de potencia ("bone special"). Durante todo el procedimiento se utiliza una irrigación profusa con suero fisiológico para evitar el sobrecalentamiento del hueso. En todos los casos se utilizó una sierra oscilante (OT7) del mismo fabricante.

Entre Abril de 2006 y Diciembre de 2006 se han tratado ocho pacientes afectados por problemas de ATM y que requerían distintas osteotomías. El procedimiento más común efectuado fue la condilectomía alta (Fig. 1) o remodelado condilar, y la eminectomía (Fig. 2). En un caso de displasia craneofacial se efectuó una osteotomía de acceso del arco cigomático para acceder al cóndilo.
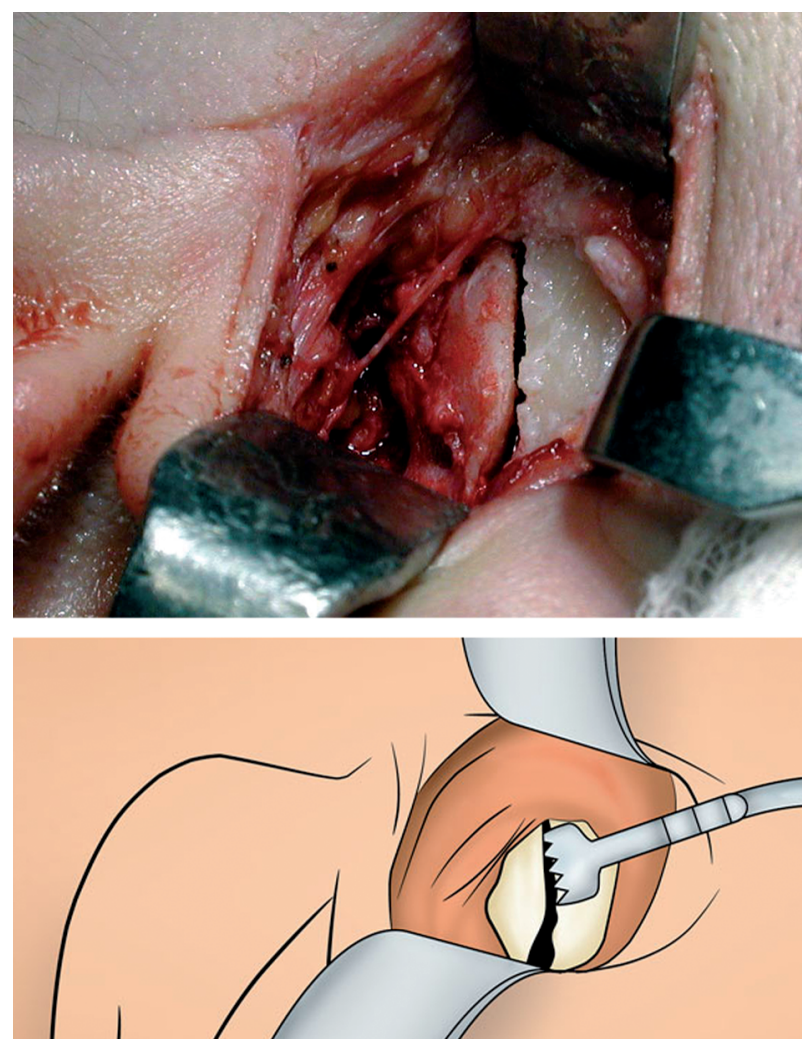

Figura 1. Condilectomía alta. Figure 1. High condylectomy.
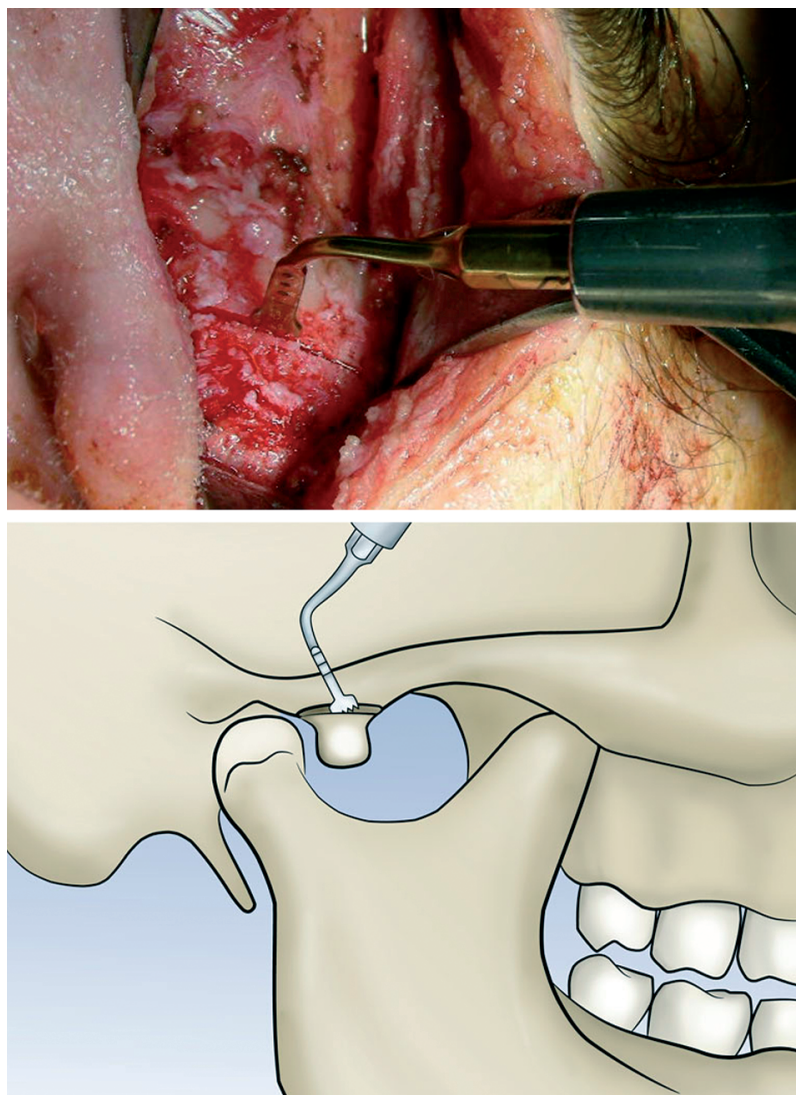

Figura 2. Eminectomía.

Figure 2. Resection of the articular eminence.

\section{Introduction}

"Piezosurgery" takes advantage of the cutting capacity of an instrument that vibrates at ultrasound frequency. The soft tissues that come into contact with the vibratory material are not injured, which makes the piezoelectric cutting tool an ideal instrument to use in limit between soft tissues and bone, ${ }^{1}$ which reduces the risk of injuring adjacent soft tissues.

In the maxillofacial region, there is an intimate relation between bone and the local nerves and blood vessels. The technique has been used in a variety of intraoral and extraoral osteotomies in the maxillofacial territory to take advantage of its "selective" cutting capacity and to minimize surgical trauma to adjacent tissues. The aim of this article is to present our experience with new applications of a piezoelectric surgical cutting tool in various extraoral osteotomies in the craniofacial territory.

\section{Material and method}

The same instrument (Medical Mectron Technology, Italy) was used to perform the osteotomies on all the patients. High-frequency oscillation at $25-30 \mathrm{KHz}$ is used to cut bone without affecting the adjacent soft tissues. The device is used at its maximum 
Además, un caso de reconstrucción secundaria de un hundimiento de la región naso-orbitaria fue tratado con injertos de cortical externa parietal, que se tomaron con la sierra oscilante conectada al bisturí piezoeléctrico (Fig. 3).

Finalmente en un caso de rinoseptoplastia post-traumática se recurrió al bisturí piezoeléctrico para efectuar las osteotomías a través de unas incisiones percutáneas en la región paranasal (Fig. 4). La osteotomía efectuada tenía un diseño "low-tohigh".

\section{Resultados}

En todos los pacientes intervenidos, el instrumento de piezocirugía permitió una osteotomía precisa y segura sin lesiones visibles en los tejidos vecinos. En la articulación temporomandibular las osteotomías fueron sencillas. En la mayor parte de casos solo fue necesario un periostotomo para separar los fragmentos osteotomizados. En la calota, la toma del injerto fue sencilla y segu-
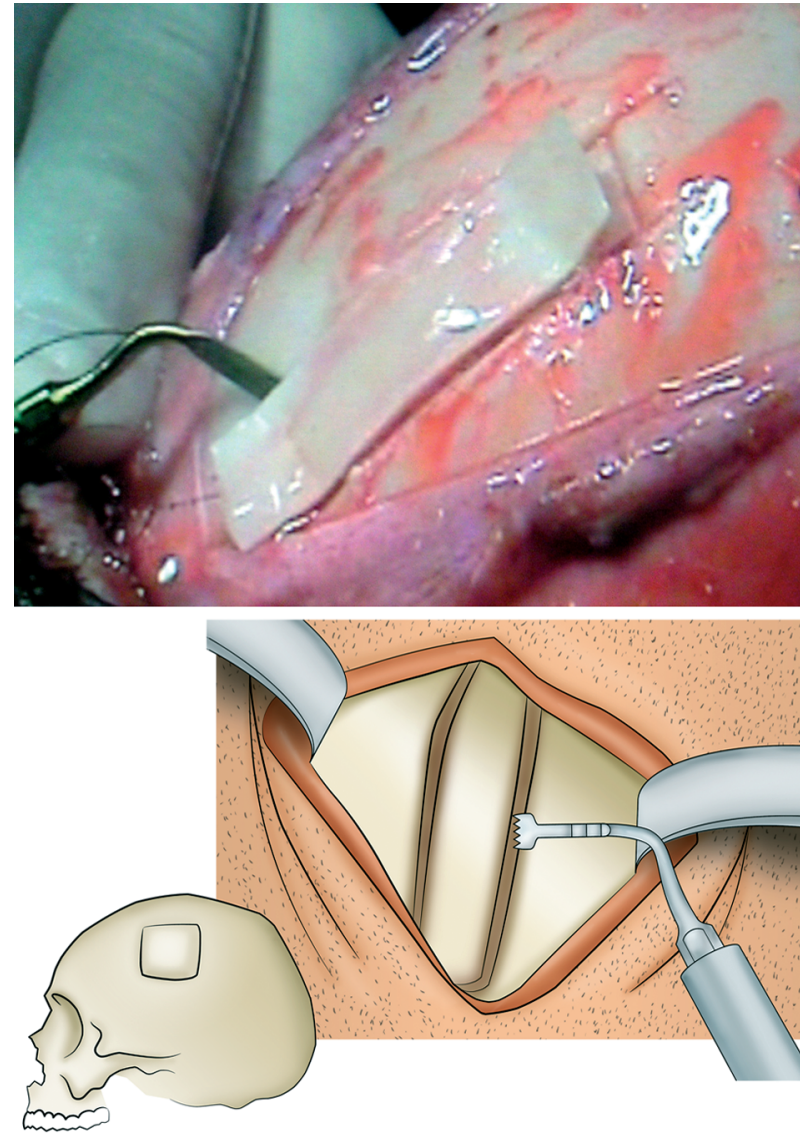

Figura 3. Toma de injerto de calota. Figure 3. Harvest of a skull graft. power level ("bone special"). Profuse irrigation with saline solution was used throughout the procedure to keep the bone from overheating. A micro-saw (OT7) from the same manufacturer was used in every case.

Between April 2006 and December 2006, eight patients with problems of the temporomandibular joint who required different osteotomies were treated. The most common procedure performed was high condylectomy (Fig. 1), or condylar reshaping, and resection of the articular eminence (Fig. 2). In a case of craniofacial dysplasia, osteotomy of the zygomatic arch was performed to obtain access to the condyle.

In addition, in a case of secondary reconstruction of naso-orbital collapse, the region was repaired with parietal external cortical grafts that were obtained with a micro-saw insert conra, pero fue evidente un alargamiento del tiempo de intervención debido a la dureza del hueso parietal. Durante la rinoplastia, la falta de visión y la dureza de la zona a fracturar dificultaron el procedimiento, en el que también se evidenció una duracion mayor de la intervención.

\section{Discusión}

En los últimos años los instrumentos de piezocirugía se han popularizado en el territorio maxilofacial. ${ }^{1-4}$ Aunque se han utilizado fundamentalmente en técnicas intraorales, ${ }^{5-7}$ también se han utilizado en diferentes osteotomías del área facial, incluyendo osteotomías segmentarias del maxilar, ${ }^{8}$ osteotomías mandibulares ${ }^{9}$ y osteoplastias craneales. ${ }^{10}$

La piezocirugía se puede utilizar para la toma de la mayor parte de los injertos óseos de la región craneofacial. Sus características de corte permiten proteger los tejidos blandos vecinos. Así, en la tuberosidad maxilar, se puede proteger la mucosa sinusal, el nervio mentoniano para toma de injertos del mentón, o el nervio alveolar inferior en la toma de rama ascendente, o bien la duramadre en la toma de hueso parietal. ${ }^{11-14}$

Hemos presentado la técnica utilizado para efectuar diferentes osteotomías de la región craneofacial, que no han sido descritas previamente en la literatura. nected to the piezoelectric surgical cutting tool (Fig. 3).

Finally, in a case of post-traumatic rhinoseptoplasty, the piezoelectric surgical cutting tool was used to make osteotomies through percutaneous incisions in the paranasal region (Fig. 4). The osteotomy had a "low-to-high" design.

\section{Results}

In all the patients operated on, the piezoelectric surgical instrument made it possible to perform an exact and safe osteotomy without visible lesions to the neighboring tissues. The osteotomies of the temporomandibular joint were simple. In most cases, only a periosteotome elevator was required to separate the osteotomized fragments. In the skull, it was simple and safe to obtain the bone graft, but the operating time was prolonged by the hardness of the parietal bone. During rhinoplasty, poor vision of the area and the hardness of the bone to be fractured made the procedure difficult. The operating time also was longer. 
La tabla externa del hueso parietal es un área donante muy útil para los cirujanos craneofaciales, no solo por su disponibilidad topográfica, sino también por la baja morbilidad e incapacidad que supone el procedimiento. ${ }^{15-17}$ El hueso se obtiene del área donde el hueso es más grueso y su diploe es rico en hueso esponjoso. La principal complicación del procedimiento es la lesión de la dura, pero a menos que se perfore, no produce morbilidad ${ }^{18}$. El bisturí piezoeléctrico ofrece la ventaja de prevenir la lesión a la dura y las complicaciones asociadas, tanto por su característica de corte selectivo, como por la forma de uso del instrumento, en el que la mano del cirujano no aplica presión sobre la zona intervenida. Además la precisión del corte permite perder menos sustancia ósea durante la osteotomía.

En la articulación temporomandibular, el bisturí piezoeléctrico permite un corte óseo seguro en el aspecto medial del cóndilo reduciendo los riesgos de lesionar la arteria maxilar interna. También en el sector medial de la eminencia, si se penetra accidentalmente en la cavidad craneal, se reducen los riesgos de lesionar los vasos meníngeos. Esta eventualidad es especialmente importante en casos de anquilosis temporomandibular, en los que existe una deformación severa de la arquitectura ósea.

La osteotomía en la rinoplastia es una de las etapas más críticas del procedimiento en sí. Un mal diseño o una mala ejecución serán resonables de un resultado estético deficiente y de potenciales complicaciones intra o postoperatorias. Nuestra práctica habitual consiste en realizar la osteotomía por via extranasal a través de dos o cuatro incisiones paranasales, por donde se introducen escoplos de 3 $\mathrm{mm}$. Esta técnica permite un mejor control operatorio y minimiza el traumatismo. Hemos utilizado esas mismsas inciiones para introducir el terminal vibratorio. En la rinoplastia, el empleo del instrumento de piezocirugía no ha aportado desde nuestro punto de vista ninguna ventaja especial.. El dificil acceso a través de la incisión percutanea complica la refrigeración de la zona osteotomizada y aumenta el riesgo de lesión térmica del hueso Dado que el riesgo de lesión de tejidos blando es insignificante, la mayor duración del procedimiento no justifican la sustitución de la técnica clásica con escoplos por vía transcutanea o endonasal. No obstante no descartamos que el empleo del instrumento por via endonasal (con un mejor acceso para la refrigeración del hueso) sea una opción a considerar.

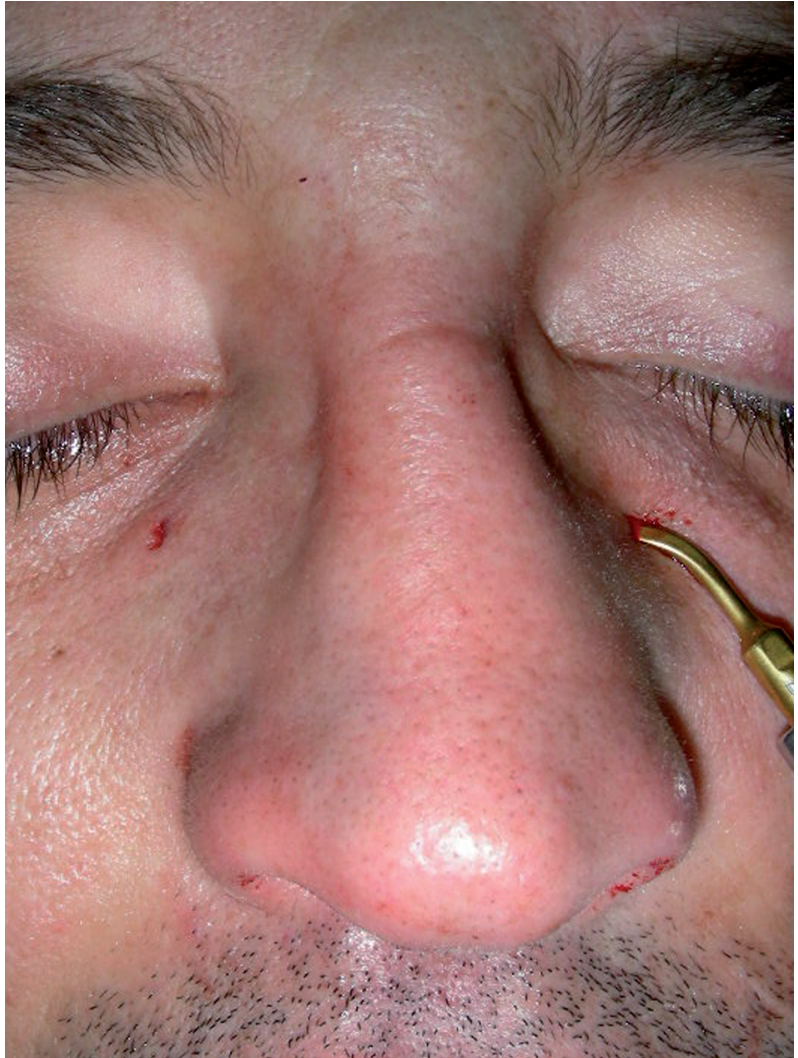

\section{Discussion}

In recent years, piezoelectric surgical cutting tools for the maxillofacial region have become popular. ${ }^{1-4}$ Although they have been used fundamentally in intraoral techniques, ${ }^{5-7}$ they also have been applied for different osteotomies of the facial area, including maxillary segmental osteotomy, ${ }^{8}$ mandibular osteotomy, ${ }^{9}$ and cranial osteoplasty. ${ }^{10}$

Piezoelectric surgery can be used to obtain most of the bone grafts made in the craniofacial region. Its cutting characteristics protect the adjacent soft tissues. Consequently, during the bone graft harvesting procedure, the sinus mucosa can be protected in the maxillary tuberosity, the mental nerve in grafts from the chin, the inferior alveolar nerve in grafts from the ascendant ramus, and the dura mater in grafts from the parietal bone. ${ }^{11-14}$

We present the technique used to perform different osteotomies in the craniofacial region that have not been described previously in the literature.

The outer table of the parietal bone is a useful donor area for craniofacial surgeons, not only because of its easy accessibility, but also because of the low morbidity and disability of the procedure. ${ }^{15-17}$ The bone is obtained from the thickest part, where the diploë has abundant cancellous bone. The main complication of the procedure is dural injury but, no morbidity occurs if the dura is not perforated. ${ }^{18}$ The piezoelectric surgical cutting tool has the advantage of preventing dural injury and avoiding the associated complications because it can be used both to cut selectively and without the surgeon having to apply pressure to the intervention site. In 
Las ventajas del procedimiento incluyen la ya mencionada inocuidad frente a los tejidos blandos, evitando su lesión accidental durante la cirugía, ${ }^{3}$ y un mejor control de la linea de osteotomía debido a las propiedades físicas del aparato. ${ }^{19}$ Las complicaciones derivadas directamente del bisturí piezoeléctrico son infrecuentes. Entre ellaa figuran la lesión térmica del hueso, el desconocimiento de los efectso a largo plazo de la técnica, y la fatiga del material. ${ }^{20}$ La queja más frecuente es que los procedimientos se alargan en comparación con intervenciones en las que se emplean sierras convencionales. En nuestra experiencia esta situación se ha evidenciado especialmente en las osteotomías nasales, y en menor medida en la toma del injerto craneal, pero ha sido insignificante en los procedimientos efectuados en la articulación temporomandibular.

\section{Conclusiones}

El bisturí piezoeléctrico con la punta adecuada se puede utilizar de forma segura en muchas de las osteotomías que se efectuan rutinariamente en el esqueleto maxilofacial. Hemos presentado nuestra experiencia con esta técnica en el manejo de la hiperplasia de cóndilo, transtornos de ATM en la que es necesaria una eminectomía, en las osteotomías laterales de la rinoplastia y en la toma de injerto de calota, situaciones todas ellas en las que no se había descrito el empleo del instrumento.

\section{Bibliografía}

1. Vercellotti T. Technological characteristics and clinical indications of piezoelectric bone surgery. Minerva Stomatol 2004; 53:207-14.

2. Eggers G, Klein J, Blank J, Hassfeld S. Piezosurgery: an ultrasound device for cutting bone and its use and limitations in maxillofacial surgery. Br J Oral Maxillofac Surg 2004; 42:451-3.

3. Siervo S, Ruggli-Milic S, Radici M, Siervo P, Jager K. Piezoelectric surgery. An alternative method of minimally invasive surgery. Schweiz Monatsschr Zahnmed 2004;114:365-77.

4. Stubinger S, Kuttenberger J, Filippi A, Sader R, Zeilhofer HF. Intraoral piezosurgery: preliminary results of a new technique. / Oral Maxillofac Surg 2005; 63:1283-7.

5. Vercellotti T, De Paoli S, Nevins M. The piezoelectric bony window osteotomy and sinus membrane elevation: introduction of a new technique for simplification of the sinus augmentation procedure. Int J Periodontics Restorative Dent 2001;21:561-7.

6. Bovi M. Mobilization of the inferior alveolar nerve with simultaneous implant insertion: a new technique. Case report. Int J Periodontics Restorative Dent 2005;25:375-83.

7. Metzger MC, Bormann KH, Schoen R, Gellrich NC, Schmelzeisen R. Inferior alveolar nerve transposition--an in vitro comparison between piezosurgery and conventional bur use. J Oral Implantol 2006;32:19-25.

8. Gruber RM, Kramer FJ, Merten HA, Schliephacke H. Ultrasonic surgery: an alternative way in orthognatic surgery of the mandible: a pilot study. Int J Oral Maxillofac Surg 2005; 34:590-3.

9. Robiony M, Polini F, Costa F, Vercellotti T, Politi M. Piezoelectric bone cutting in multipiece maxillary osteotomies. J Oral Maxillofac Surg 2004 ;62:759-61. addition, the precision of the cut means that less bone substance is lost during osteotomy.

In the temporomandibular joint, the piezoelectric surgical device allows bone to be cut safely on the medial condylar aspect, thus reducing the risk of injuring the internal maxillary artery. In the medial part of the articular eminence, the risk of injuring meningeal vessels is reduced if the cranial cavity is penetrated accidentally. This eventuality is especially important in cases of temporomandibular ankylosis, in which there is severe deformation of the bone architecture.

In rhinoplasty, the osteotomy is one of the most critical stages of the procedure. Poor design or defective execution will result in deficient esthetic results and possible intra- or postoperative complications. Our usual practice is to perform the osteotomy using an extranasal approach with two or four paranasal incisions in which $3 \mathrm{~mm}$ chisels are introduced. This technique allows better operative control and is less traumatic. We used the same incisions to introduce the vibratory insert. Use of the piezoelectric cutting tool in rhinoplasty did not offer any special advantage from our viewpoint. The difficulty of access through the percutaneous incision complicates the refrigeration of the osteotomy zone and increases the risk of thermal injury to the bone. Since the risk of soft tissue injury is insignificant, the longer duration of the procedure does not justify replacing the classic chisel technique through the transcutaneous or endonasal approach. Nonetheless, we cannot rule out the possibility that using the instrument by an endonasal approach (which improves access for bone refrigeration) would be an option to consider.

The advantages of the procedure include its already mentioned innocuousness for soft tissues, which prevents accidental injury during surgery, ${ }^{3}$ and better control of the osteotomy due to the physical properties of the device. ${ }^{19}$ Complications derived directly from the piezoelectric surgical device are infrequent. These complications include thermal damage to the bone, our lack of knowledge of the long-term effects of the technique, and material fatigue. ${ }^{20}$ The most frequent complaint is that procedures are more time-consuming than interventions performed with conventional cutting instruments. This occurred in our experience, especially in the nasal osteotomy and, to a lesser extent, in harvesting the skull graft, but it was insignificant in the procedures on the temporomandibular joint.

\section{Conclusions}

The piezoelectric surgical cutting tool, with the proper insert, can be used safely in many osteoto- 
10. Kotrikova B, Wirtz R, Krempien R, Blank J, Eggers G, Samiotis A, Muhling J. Piezosurgery--a new safe technique in cranial osteoplasty? Int / Oral Maxillofac Surg 2006;35:461-5.

11. Chiriac G, Herten M, Schwarz F, Rothamel D, Becker J. Autogenous bone chips: influence of a new piezoelectric device (Piezosurgery) on chip morphology, cell viability and differentiation. / Clin Periodontol 2005;32:994-9.

12. Held U, Bormann KH, Schmelzeisen R, Gellrich NC. Augmentation of alveolar ridge defects: autologous bone transplant from the zygomatic alveolar crest-a new technique. Schweiz Monatsschr Zahnmed 2005;115:692-703.

13. Berengo M, Bacci C, Sartori M, Perini A, Della Barbera M, Valente M. Histomorphometric evaluation of bone grafts harvested by different methods. Minerva Stomatol 2006;55:189-98.

14. Sivolella S, Berengo M, Scarin M, Mella F, Martinelli F. Autogenous particulate bone collected with a piezo-electric surgical device and bone trap: a microbiological and histomorphometric study. Arch Oral Biol 2006 Jul 3.

15. Pensley J, MacCarthy JG. The calvarial donor site: an anatomis study in cadavers. Plast Reconst Surg 1985;75:648-51.

16. Jackson IT, Helden G, Marx R. Skull bone grafts in maxillofacial and craniofacial surgery. J Oral Maxillofac Surg 1986; 44:949-55.

17. Tessier P. Autogenous bone grafts taken from the calvarium for facial and clinical applications. Clin Plast Surg 1984; 74:687-93.

18. Habal M. Craniofacial Surgery. In: Habal M, Redii AH. Bone grafts and Bone substitutes. WB Saunders, Philadelphia 1992: 346-65.

19. Torrella F, Pitarch J, Cabanes G, Anitua E. Ultrasonic osteotomy for the surgical approach of the maxillary sinus: a technical note. Int J Oral Maxillofac Implants 1998;23:697-700.

20. Brujan EA. The role of cavitation microjets in the therapeutic applications of ultrasound. Ultrasound Med Biol 2004;30:381-7. mies that are performed routinely on the maxillofacial skeleton. We have reported here presented our experience with this instrument in the management of condylar hyperplasia, temporomandibular joint conditions requiring resection of the articular eminence, lateral osteotomy in rhinoplasty, and in harvesting skull grafts, all situations in which the use of this instrument has not been reported previously. 